Available online at http://bjas.bajas.edu.iq

https://doi.org/10.37077/25200860.2021.34.2.14 College of Agriculture, University of Basrah

Basrah J. Agric. Sci., 34(2), 184-192, 2021
Basrah Journal of Agricultural Sciences

E-ISSN: 2520-0860

ISSN $1814-5868$

\title{
The effect of a Forest Biomass Supplement on Morphophysiological Parameters of Calves
}

\author{
Vladimir V. Zaitsev ${ }^{1 *}$, Ivan N. Mayorov' ${ }^{1}$ Lilia M. Zaitseva1, Vasily P. Korotky ${ }^{2}$, \\ Viktor A. Ryzhov ${ }^{2} \&$ Nikolay P. Buryakov ${ }^{3}$ \\ ${ }^{1}$ Samara State Agrarian University, 2 Uchebnaya st., Ust-Kinelsky, 446442, Russia \\ ${ }^{2}$ Science and Technology Center "Khiminvest", 6/1 Nizhne-Volzhskaya naberezhnaya, \\ Nizhny Novgorod, 603001, Russia \\ ${ }^{3}$ Russian Timiryazev State Agrarian University, 49 Timiryazevskaya st., Moscow, 127550, \\ Russia \\ *Corresponding author: zaitsev-vladimir@bk.ru \\ Received 17 ${ }^{\text {th }}$ March 2021; Accepted; $28^{\text {th }}$ June 2021 ; Available online 4 November 2021
}

\begin{abstract}
Breeding, preserving, and successfully rearing young animals resistant to various environmental influences is one of the main parameters of effective livestock management. The study aimed to study the indicators of natural resistance and the growth rate of calves under the influence of dietary supplements. The studies were carried out on four groups of black-and-white calves, 10 heads each, at the age of 2-5 months. The dairy calves of the control group were fed according to the ration adopted on the farm (basic ration, including cereal-legume hay, whole milk, milk replacer, concentrates, chalk, salt). In addition to the main diet, the animals of the experimental groups were given a dietary supplement. At 2-3, 3-4, and 4-5, months of age, calves were given 12-23, 19-38, and 23-47 g.head of $^{-1}$ dietary supplement per day, respectively. The article deals with the effect of a forest biomass supplement on the morphophysiological parameters of calves. Biochemical blood analysis and the features of metabolic processes in the bodies of animals are studied. The results indicated that the use of a dietary supplement at a dosage of 30 $\mathrm{g} /$ head of cattle per day contributes to the highest increase $(9.9 \%)$ in live weight gain of experimental animals and an improvement in natural resistance parameters (bactericidal activity of blood serum, phagocytic activity of neutrophils). Based on the data of biochemical and haematological blood tests, the authors conclude that the inclusion of a dietary supplement in the diet of calves has a positive effect on the indices of natural resistance and the course of nitrogen metabolism.
\end{abstract}

Keywords: dietary supplement, live weight gain, biochemistry, resistance 
Zaitsev et al,/Basrah J. Agric. Sci., 34(2): 184-192, 2021

\section{Introduction}

The resistance of the animal organism to unfavourable environmental factors is a dynamic parameter and is determined by both the genetics and the effect of various environmental factors (Karamaeva \& Zaitsev, 2010; Zaytsev, 2019). Because of this, it is possible to exert direct control over the development and manifestation of different body defence factors. Providing animals with good diet and favourable rearing environments, which conform as closely as possible to the biological features of the organism developed during evolutionary growth, aids in the production and manifestation of body defensive mechanisms (Gorelik \& Barashkin, 2016; Kiselenko, 2020).

Newborns of all animal species have a physiological immune deficiency. A decrease in the parameters of nonspecific resistance of the organism (blood serum bactericidal activity (BSBA), blood serum lysozyme activity (BSLA), and phagocytic activity of blood neutrophils $(\mathrm{PABN})$ ) when rearing young animals in conditions of intensive technologies aggravates the manifestation of immunodeficiency. Compensation of physiological immune deficiency with an increase in natural resistance in new-born occurs due to cellular and humoral factors of colostrum (Loretts et al., 2019).

In this regard, the formation and use of various dietary supplements aimed at increasing the resistance of the animal organism is an urgent issue for research and practice.

The goal of our experiment was to study the characteristics of metabolic processes in the calves' bodies based on biochemical blood tests and to analyse the growth rate of animals and parameters of natural resistance under the influence of a combination of nutritional supplements.

\section{Materials \& Methods}

\section{General research scheme}

The studies were carried out in normal work conditions on four groups of 10 calves in each group of the black-and-white breed aged 2 months with an average of live body weight of $(72.65 \mathrm{~kg})$. The study was in compliance with the International Recommendations of the European Convention for the Protection of Vertebrate Animals used in Experimental Research (Council of Europe, 1986). The live weight of calves when setting up for the experiment was $73.28 \mathrm{~kg}$ in the control group, $72.24 \mathrm{~kg}$ in experimental group 1, $72.33 \mathrm{~kg}$ in experimental group 2, and $72.75 \mathrm{~kg}$ in experimental group 3 .

The milk-fed calves of the control group were fed according to the ratio adopted at the farm (basic diet - BD). Animals of the 1st, 2nd, and 3rd experimental groups, in addition to the BD, were given a dietary supplement. The supplement was administered orally by syringe daily in the morning feed.

The supplement was administered to calves: at the age of 2-3 months, in experimental group 1 12 g.head $^{-1}$ per day, experimental group 218 g/head, and experimental group 323 g.head $^{-1}$ per day; at the age of 3-4 months, in experimental group 119 g.head $^{-1}$ per day, experimental group $228 \mathrm{~g} / \mathrm{head}$, and experimental group $338 \mathrm{~g} / \mathrm{head}$ per day; at the age of 4-5 months, in experimental group 123 g.head $^{-1}$ per day, experimental group 235 g.head $^{-1}$, and experimental group 347 g.head ${ }^{-1}$ per day. The duration of the experiment equaled 90 days. Animals of the control and experimental groups were housed in the same facility. 


\section{Composition of the dietary supplement}

The dietary supplement is a mixture of natural ingredients containing glycerin, pine extract, sugar, activated carbon, flaxseed, and table salt. Glycerin is the main component of all fats (triglycerides). It serves as a source of energy.

Pine or spruce needle extract is a natural vitamin source. Pine and spruce needles contain carotene, chlorophyll, xanthophyll, and other substances that are important for metabolism and in the synthesis of many vitamins in the body. Moreover, carotene, or provitamin A, is contained in pine and spruce needles in a dosage twice as high as in carrots. In winter and autumn, vitamin deficiency can be replenished by adding pine and spruce needles rich in vitamins $\mathrm{A}, \mathrm{C}$, $\mathrm{B} 2, \mathrm{~K}, \mathrm{E}$, and $\mathrm{P}$ to the diet.

Sugar is not only a source of energy for ruminants but is also necessary for the normal functioning of the rumen microflora.

Activated carbon has a high ability to retain (adsorb) various substances, liquids, and gases on its surface. Activated carbon also adsorbs various toxic substances.

Flaxseed is rich in fat $(36 \%)$ and protein (24\%) and easily digestible. Therefore, it is especially valuable for young farm animals. Flaxseed swells in the gastrointestinal tract, forming slimy solutions that have excellent dietary properties. They were bred to improve the functioning of the gastrointestinal tract.

Table salt is necessary for animals to maintain the acid-base balance in the blood and water balance in the body. Without table salt, the correct functioning of the muscles, stomach, and nervous system of the animal is impossible. Salt is not produced by the body and does not come in sufficient quantities from grass, hay, and animal feed. Salt is involved in metabolic processes, due to which each cell receives the right amount of nutrients. It enhances the taste of food, which affects the growth of the animal's appetite and has antibacterial properties, protecting the body from the development of harmful bacteria.

During the study period, we determined the chemical composition of the given feed. Live weight gains (gross, daily average) were calculated based on the individual weighing of experimental animals.

\section{Methods}

At the beginning and the end of the experiment, blood tests were carried out in the animals of the control and experimental groups. We measured the levels of their hemoglobin, red blood cells, white blood cells, haematocrit, total protein, albumin, globulins, creatinine, urea, total bilirubin, total cholesterol, calcium, phosphorus, alkaline phosphatase, glucose, aspartate aminotransferase (AST), and alanine aminotransferase (ALT) We determined the level of nonspecific immunity in the blood of experimental animals $(\mathrm{n}=3)$. BSBA was studied according to the method of O.V. Bukharin \& Sozykin (1979) using a test culture of E. coli $\mathrm{O}_{111}$.

BSLA was studied according to the method of Bukharin (1971) using a daily culture of Micrococcus Lusodeicticus (strain 2665 GKI named after L.A. Tarasevich).

PABN was determined according to the method of Ivanov \& Chukhlovin (1967) using as a test culture of E. coli $\mathrm{O}_{111}$, grown for a day on meat-and-peptone agar (MPA). 
The data was analysed due to analysis of variance within a statistical program. Data were expressed as the arithmetic mean (M), the rootmean-square error $( \pm \mathrm{m})$, and the significant difference $(\mathrm{P})$. The study results were considered highly significant at $\mathrm{P}<0.001$ and significant at $\mathrm{P}$
$<0.01$ and $\mathrm{P}<0.05$. When $\mathrm{P}>0.05$, differences are not significant.

\section{Results \& Discussion}

The data on the Live weight of calves of the control and experimental groups are presented in table

Table (1): Productivity of milk-fed calves ( $n=10$ /group, $M \pm m$ ).

\begin{tabular}{|c|c|c|c|c|}
\hline \multirow{2}{*}{ Parameter } & \multicolumn{4}{|l|}{ Group } \\
\hline & \multirow{2}{*}{ control } & \multirow[t]{2}{*}{ 1st experimental } & \multirow[t]{2}{*}{ 2nd experimental } & \multirow[t]{2}{*}{ 3rd experimental } \\
\hline Live weight, $\mathrm{kg}$ : & & & & \\
\hline $\begin{array}{l}\text { at the beginning of the } \\
\text { experiment }\end{array}$ & $73.28 \pm 2.0$ & $72.24 \pm 1.6$ & $72.33 \pm 1.7$ & $72.75 \pm 1.4$ \\
\hline $\begin{array}{l}\text { at the end of the } \\
\text { experiment }\end{array}$ & $140.17 \pm 1.2$ & $141.27 \pm 4.38$ & $145.84 \pm 2.1^{*}$ & $144.09 \pm 1.5$ \\
\hline Gross growth, kg & $66.89 \pm 1.41$ & $69.03 \pm 1.66$ & $73.51 \pm 1.05^{* *}$ & $71.34 \pm 1.23$ \\
\hline $\begin{array}{l}\text { Average daily growth, } \\
\text { g }\end{array}$ & $743.22 \pm 14.70$ & $766.96 \pm 18.5$ & $816.72 \pm 12.01^{* * *}$ & $774.3 \pm 14.21$ \\
\hline $\begin{array}{l}\text { In \% to the control } \\
\text { group }\end{array}$ & 100.0 & 100.8 & 104.0 & 102.8 \\
\hline
\end{tabular}

It was found that during the period of our experiment, claves of the $2^{\text {nd }}$ experimental group developed the most intensively, receiving a dietary supplement in a dosage of 18-35 g.head ${ }^{-1}$ of cattle per day. Thus, at the end of the experiment, the calves of the 2 nd experimental group had exceeded the control group body weight by $6.6 \mathrm{~kg}$, or $4.0 \%$, and their average daily weight gain by $73.5 \mathrm{~g}$ or $9.9 \%$, respectively, with a significant difference. The calves of the 1 st and 3rd experimental groups had also exhibited higher (not significant) average daily weight gain by $23 \mathrm{~g}(3.2 \%)$ and $31.1 \mathrm{~g}(4, \%)$, respectively, than those of control group.

The increase in the average daily gain in live weight of milk-fed calves in the experimental groups can be explained in the following way. The dietary supplement they received in various dosages supplied their bodies with nutrients and biologically active and energetic substances. These substances had an antibacterial and immunomodulatory effect and promoted the development of beneficial microflora in the gastrointestinal tract.

The study of blood picture and biochemical parameters of the blood allows assessing the impact of physiological processes in the body (Ivanov \& Chukhlovin, 1967; Koryakina \& Borisov, 2016; Zemlyanukhina, 2016).

Blood picture and biochemical parameters of the blood of calves from the control and experimental groups at the beginning and end of the experiment are presented in tables (2) and (3). All figures were within the normal ranges of calves. Groups have not significantly influenced all traits except the concentration of urea at the end of the study $(\mathrm{P}<0.05)$. 
Table (2): Blood picture and biochemical parameters of the blood of experimental animals at the beginning of the experiment $(M \pm m, n=3$ /group).

\begin{tabular}{|c|c|c|c|c|}
\hline \multirow{2}{*}{ Parameter } & \multicolumn{4}{|c|}{ Experimental Groups } \\
\hline & control & $1 \mathrm{st}$ & $2 \mathrm{nd}$ & $3 \mathrm{rd}$ \\
\hline White blood cells, $10^{9} / 1$ & $10.20 \pm 0.65$ & $9.34 \pm 1.06$ & $9.56 \pm 0.48$ & $9.64 \pm 1.16$ \\
\hline Red blood cells, $10^{12} / 1$ & $11.88 \pm 0.96$ & $10.46 \pm 0.34$ & $9.74 \pm 1.57$ & $10.46 \pm 0.34$ \\
\hline Hemoglobin, g... $\mathrm{L}^{-1}$ & $99.3 \pm 3.16$ & $93.9 \pm 4.16$ & $88.9 \pm 8.20$ & $89.9 \pm 4.10$ \\
\hline Total protein, g.L $\mathrm{L}^{-1}$ & $64.14 \pm 2.40$ & $63.0 \pm 2.52$ & $62.20 \pm 2.12$ & $60.0 \pm 2.40$ \\
\hline Albumins, g.. - $^{-1}$ & $26.9 \pm 0.62$ & $26.75 \pm 0.39$ & $27.15 \pm 0.90$ & $26.65 \pm 0.42$ \\
\hline Globulins, g..L ${ }^{-1}$ & $35.40 \pm 2.29$ & $33.47 \pm 2.55$ & $36.6 \pm 1.18$ & $34.47 \pm 2.55$ \\
\hline A/G coefficient & 0.75 & 0.79 & 0.74 & 0.77 \\
\hline Urea, mmol.L ${ }^{-1}$ & $4.82 \pm 0.57$ & $4.57 \pm 0.20$ & $5.41 \pm 0.63$ & $4.88 \pm 0.29$ \\
\hline Creatinine, $\mathrm{mmol} \mathrm{L}^{-1}$ & $69.17 \pm 11.72$ & $80.15 \pm 2.21$ & $81.9 \pm 3.66$ & $76.15 \pm 3.25$ \\
\hline ALT, IU.L IL $^{-1}$ & $8.33 \pm 1.09$ & $7.37 \pm 0.28$ & $7.01 \pm 0.35$ & $7.37 \pm 0.28$ \\
\hline AST, IU.L ${ }^{-1}$ & $72.8 \pm 16.12$ & $60.93 \pm 5.98$ & $49.46 \pm 2.71$ & $60.93 \pm 5.98$ \\
\hline Alkaline phosphatase, IU/l & $942.0 \pm 167.8$ & $948.1 \pm 128.0$ & $844.7 \pm 177.5$ & $908.1 \pm 152.0$ \\
\hline Total cholesterol, mmol.L $\mathrm{L}^{-1}$ & $3.83 \pm 0.38$ & $4.79 \pm 0.26$ & $4.39 \pm 0.42$ & $4.79 \pm 0.26$ \\
\hline Glucose, mmol.L ${ }^{-1}$ & $6.45 \pm 0.34$ & $6.68 \pm 1.15$ & $6.91 \pm 0.16$ & $6.68 \pm 1.15$ \\
\hline Calcium, mmol.L ${ }^{-1}$ & $2.49 \pm 0.13$ & $2.57 \pm 0.04$ & $2.38 \pm 0.10$ & $2.57 \pm 0.04$ \\
\hline Phosphorus, mmol.L ${ }^{-1}$ & $3.09 \pm 0.44$ & $3.68 \pm 0.38$ & $3.0 \pm 0.51$ & $3.68 \pm 0.38$ \\
\hline $\mathrm{Ca} / \mathrm{P}$ ratio & 0.80 & 0.70 & 0.79 & 0.70 \\
\hline
\end{tabular}

Haemoglobin in the blood of animals acts as an oxygen carrier to the haematopoietic organs. The amount of haemoglobin in the calves of the control is 98.20 g. $\mathrm{L}^{-1} . \mathrm{Hb}$ of the $1^{\text {st }}, 2^{\text {nd }}$ and $3^{\text {rd }}$ groups were higher than control by 9.2 (9.3\%), $11.6(11.8 \%)$, and $9,0 \mathrm{~g} / \mathrm{l}(9.1 \%)$.
$\mathrm{RBC}$ of $1^{\text {st }}, 2^{\text {nd }}$ and $3^{\text {rd }}$ experimental group, were $11.89 \times 10^{12} . \mathrm{L}^{-1}, 11.82 \times 10^{12} . \mathrm{L}^{-1}$, and 11.80 $\times 10^{12} \cdot \mathrm{L}^{-1}$ respectively. Control recorded lower insignificant value $\left(10.94 \times 10^{12} \cdot \mathrm{L}^{-1}\right)$.

Table (3): Blood picture and biochemical parameters of the blood of experimental animals at the end of the experiment $(M \pm m, n=3$ /group $)$

\begin{tabular}{lllll}
\hline \multirow{2}{*}{ Parameter } & \multicolumn{4}{c}{ Experimental Groups } \\
\cline { 2 - 5 } & control & 1st & 2nd & 3rd \\
\hline White blood cells, $10^{9} . \mathrm{L}^{-1}$ & $9.98 \pm 0.14$ & $10.60 \pm 0.71$ & $10.69 \pm 0.22$ & $10.67 \pm 0.71$ \\
\hline Red blood cells, $10^{12} . \mathrm{L}^{-1}$ & $10.94 \pm 0.55$ & $11.89 \pm 0.31$ & $11.82 \pm 1.18$ & $11.80 \pm 0.31$ \\
\hline Hemoglobin, g.L & $98.2 \pm 4.6$ & $107.4 \pm 1.70$ & $109.8 \pm 7.70$ & $107.2 \pm 1.65$ \\
\hline Total protein, g.L & $67.06 \pm 2.21$ & $70.87 \pm 0.38$ & $73.72 \pm 0.51$ & $71.87 \pm 0.38$ \\
\hline Albumins, g.L ${ }^{-1}$ & $24.62 \pm 1.86$ & $27.95 \pm 1.03$ & $31.75 \pm 1.99$ & $27.95 \pm 1.03$ \\
\hline Globulins, g.L & $42.44 \pm 2.14$ & $41.92 \pm 1.30$ & $41.97 \pm 1.81$ & $41.92 \pm 1.30$ \\
\hline A/G coefficient & 0.58 & 0.67 & 0.76 & 0.67 \\
\hline Urea, mmol.L & $6.29 \pm 0.06$ & $4.62 \pm 0.28^{*}$ & $4.72 \pm 0.19^{*}$ & $4.80 \pm 0.24^{*}$ \\
\hline Creatinine, mmol.L m $^{-1}$ & $93.5 \pm 7.34$ & $84.23 \pm 1.83$ & $82.44 \pm 2.23$ & $84.0 \pm 1.83$ \\
\hline ALT, IU.L & $19.59 \pm 1.23$ & $19.82 \pm 1.58$ & $19.82 \pm 1.55$ & $19.82 \pm 1.58$ \\
\hline
\end{tabular}


Zaitsev et al,/Basrah J. Agric. Sci., 34(2): 184-192, 2021

\begin{tabular}{|c|c|c|c|c|}
\hline \multirow{2}{*}{ Parameter } & \multicolumn{4}{|c|}{ Experimental Groups } \\
\hline & control & $1 \mathrm{st}$ & $2 \mathrm{nd}$ & $3 \mathrm{rd}$ \\
\hline AST, IU.L ${ }^{-1}$ & $59.32 \pm 2.21$ & $65.64 \pm 1.88$ & $65.87 \pm 1.74$ & $65.60 \pm 1.90$ \\
\hline $\begin{array}{l}\text { Alkaline phosphatase, } \\
\text { IU.L-1 }\end{array}$ & $354.9 \pm 19.3$ & $323.3 \pm 20.4$ & $272.1 \pm 27.8$ & $323.3 \pm 20.4$ \\
\hline Total cholesterol, mmol.L $\mathrm{L}^{-1}$ & $3.90 \pm 0.15$ & $3.64 \pm 0.20$ & $3.72 \pm 0.22$ & $3.84 \pm 0.26$ \\
\hline Glucose, mmol.L ${ }^{-1}$ & $4.59 \pm 0.12$ & $4.69 \pm 0.28$ & $4.73 \pm 0.16$ & $4.60 \pm 0.22$ \\
\hline Calcium, mmol.L $\mathrm{L}^{-1}$ & $2.60 \pm 0.08$ & $2.73 \pm 0.09$ & $2.46 \pm 0.21$ & $2.73 \pm 0.09$ \\
\hline Phosphorus, mmol.L ${ }^{-1}$ & $3.34 \pm 0.19$ & $3.48 \pm 0.20$ & $2.90 \pm 0.49$ & $3.48 \pm 0.20$ \\
\hline $\mathrm{Ca} / \mathrm{P}$ ratio & 0.78 & 0.78 & 0.85 & 0.78 \\
\hline
\end{tabular}

$* \mathrm{P}<0.05$

There was a slight increase in the number of WBC of calves of the experimental groups compared to the control group by $6.2-7.1 \%$.

Proteins are the main constituent of the blood. They maintain osmotic pressure and blood $\mathrm{pH}$, play an important role in the formation of hormones, carbohydrates, as well as lipids, and other essential substances. In the protective activity of the body, their role is vital. They participate in water metabolism, the transfer of nutrients and metabolic products, as well as blood clotting. The total protein content in the blood of calves in the control group was 67.06 $\mathrm{g} / \mathrm{l}$. In the 1st, 2nd, and 3rd experimental groups, this parameter exceeded the control group, respectively, by 3.81 g.L $\mathrm{L}^{-1}(5.6 \%), 6,6$ g.L. $\mathrm{L}^{-1}$ (9.9\%), and 4.81 g.L ${ }^{-1}(7.2 \%)$.

At the end of the experiment, there was a tendency to an increase in the concentration of total protein in the blood of experimental animals in comparison with control animals (by 5.6$9.9 \%)$, and a decrease $(\mathrm{P}<0.05)$ in the level of urea by $23.3-26.5 \%$.

The concentration of creatinine in the blood of calves from the experimental groups was lower than that in the control by $9.9-11.8 \%$, which may indicate a more efficient nitrogen metabolism (Zaytsev, 2019).
In the blood of the animals of the experimental groups, there are higher parameters of the activity of ATSs, which carry out the transfer of amino groups from amino acids to keto acids Thus, the ATS in the blood of the control group was 59.32 IU.L $^{-1}$. In experimental groups, this indicator was higher by $10.6 \%$ (group 1), 11.0\% (group 2), and 10.5\% (group 3).

An important role in the body also belongs to carbohydrate metabolism. In our studies, in the blood of calves receiving a dietary supplement, the glucose level was slightly higher (by $2.1 \%$ in group 1 , by $3.0 \%$ in group 2 , and by $0.2 \%$ in group 3), which may indicate a higher energy supply in their body.

It should be noted a decrease in the cholesterol content in animals of the 1st experimental group by $6.7 \%$, in the 2 nd experimental group by $4.6 \%$, and in the 3rd experimental group by $1.5 \%$, compared with the control group. This parameter may indirectly reflect the improvement in the functional activity of the liver.

The level of natural resistance of the animal organism and their adaptive abilities are of particular importance. In this regard, we have determined the factors of the natural resistance of animals in comparison with the control group (Tables 4 and 5). 
Table (4): Parameters of broad-spectrum resistance of the blood of experimental animals at the beginning of the experiment $(M \pm m, n=3$ /group).

\begin{tabular}{lllll}
\hline \multirow{2}{*}{ Parameter } & \multicolumn{4}{c}{ Experimental Groups } \\
\cline { 2 - 5 } & control & 1st & 2nd & 3rd \\
\hline $\begin{array}{l}\text { Blood serum bactericidal } \\
\text { activity (BSBA), } \%\end{array}$ & $43.2 \pm 3.4$ & $43.53 \pm 2.0$ & $42.38 \pm 2.4$ & $42.56 \pm 2.1$ \\
\hline Phagocytic activity (PA), \% & $23.5 \pm 2.6$ & $23.7 \pm 1.66$ & $23.6 \pm 2.26$ & $23.7 \pm 1.66$ \\
\hline $\begin{array}{l}\text { Phagocytic number (PN), } \\
\text { phagocytosed microbial cells }\end{array}$ & $0.36 \pm 0.12$ & $0.33 \pm 0.07$ & $0.31 \pm 0.04$ & $0.31 \pm 0.07$ \\
\hline Lysozyme, mcg/ml of serum & $0.57 \pm 0.03$ & $0.55 \pm 0.02$ & $0.57 \pm 0.01$ & $0.53 \pm 0.02$ \\
\hline
\end{tabular}

Many researchers have achieved an increase in the indices of natural resistance of newborn calves through the use of various biologically active substances (Koryakina \& Borisov, 2016; Kochish et al., 2019; Topuriya \& Belyaeva, 2019).

In present study, it was noted that these parameters of different groups at the beginning of the experiment were similar (Table 4).

At the end of the experiment, some differences were observed in calves from the control and experimental groups in terms of natural resistance. The BSBA of the calves of the experimental groups was higher than that of the control animals by $5.1 \%$ (the 1 st experimental group), $13.5 \%$ (the 2nd experimental group), and $6.8 \%$ (the 3rd experimental group). The content of lysozyme in the blood serum in the experimental groups was at the level of 0.63-0.70 $\mu \mathrm{g} \cdot \mathrm{ml}^{-1}$.

Table (5): Parameters of nonspecific resistance of the blood of experimental animals at the end of the experiment $(M \pm m, n=3 /$ group$)$

\begin{tabular}{|c|c|c|c|c|}
\hline \multirow{2}{*}{ Parameter } & \multicolumn{4}{|c|}{ Experimental Groups } \\
\hline & control & $1 \mathrm{st}$ & 2nd & $3 \mathrm{rd}$ \\
\hline $\begin{array}{l}\text { Blood serum bactericidal activity } \\
\text { (BSBA), } \%\end{array}$ & $60.1 \pm 2.2$ & $63.2 \pm 2.9$ & $68.24 \pm 2.8^{*}$ & $64.2 \pm 2.8$ \\
\hline Phagocytic activity (PA), \% & $28.3 \pm 2.80$ & $31.2 \pm 1.9$ & $35.8 \pm 1.25^{*}$ & $35.2 \pm 0.92^{*}$ \\
\hline $\begin{array}{l}\text { Phagocytic number }(\mathrm{PN}) \text {, } \\
\text { phagocytosed microbial cells }\end{array}$ & $1.1 \pm 0.01$ & $1.2 \pm 0.01$ & $1.10 \pm 0.01$ & $1.1 \pm 0.01$ \\
\hline Lysozyme, $\mathrm{mcg} \mathrm{ml}^{-1}$ of serum & $0.63 \pm 0.02$ & $0.66 \pm 0.07$ & $0.70 \pm 0.07$ & $0.68 \pm 0.07$ \\
\hline
\end{tabular}

One of the main cellular factors of the natural resistance of the calves' organism is the PABN, characterized by the number of bacteria captured by white blood cells. The highest PABN was noted in the experimental groups, especially in the 2nd and 3rd ones. The calves of the experimental groups had exceeded the control group by $10.2-26.5 \%$.

The PN, which is determined by the average number of phagocytosed bacteria by one neutrophil and determines the phagocytic activity 
of neutrophils in the control and experimental groups, was at the level of 1.1-1.2.

Thus, based on the data of biochemical and haematological blood tests, it follows that the inclusion of a dietary supplement in the diets of calves has a positive effect on the course of nitrogen metabolism in the body of animals and parameters of natural resistance.

\section{Conclusion}

Based on our study, it can be concluded that the inclusion of a dietary supplement in a dosage of 18-35 g/head of cattle per day in the diet contributed to the greatest increase in live weight gain in experimental animals by $9.9 \%$ and an improvement in natural resistance parameters.

\section{Acknowlwdgments}

None.

\section{Conflict of interests}

The authors declare no conflict of interest.

\section{ORCID:}

\section{Nikolay P. Buryakov}

ORCID: 0000-0002-6776-0835

\section{References}

Bukharin, O. V. (1971). Certificate No. 23 for a rationalization proposal: "A calculation table for determining the amount of lysozyme in blood serum using the turbidometric method". OGMI.

Bukharin, O. V., \& Sozykin, V. L. (1979). Photonephelometric method for determining the bactericidal activity of blood. In Bukharin, O.V. (Ed.). Factors of natural immunity. Orenburg (in Russian), p. 43-45.

Council of Europe. (1986). European Convention for the Protection of Vertebrate Animals used for Experimental or Other Scientific Purposes (ETS n 123). Strasbourg. https://docs.cntd.ru/document/901909691
Gorelik, A. S., \& Barashkin, M. I. (2016). Povysheniye immuniteta telyat $\mathrm{v}$ molochnyy period putem primeneniya biotekhnologicheskogo preparata "Al'bitBio" [Increasing the immunity of calves during the preweaning period by using the "ALBIT-BIO" biotechnological product]. Agrarnyi vestnik Urala, 11, 17-22 (in Russian). http://agvu.urgau.ru/ru/19joomla/1065-a-s-gorelik-m-i-barashkin-povyshenieimmuniteta-telyat-v-molochnyj-period-putemprimeneniya-biotekhnologicheskogo-preparata-albitbio.html

Ivanov, A. I., \& Chukhlovin, B. V. (1967). The method of determining the absorption and digestion capacity of neutrophils. Laboratornoye delo, 10, 610-613 (In Russian).

Karamaeva, A. S., \& Zaitsev, V. V. (2010). Dinamika pokazateley yestestvennoy rezistentnosti telyat raznykh porod s vozrastom [Dynamics of natural resistance parameters in calves of different breeds with age]. Izvestiya Orenburgskogo gosudarstvennogo agrarnogo universiteta, 3, 195-197 (in Russian). https://orensau.ru/ru/component/docman/doc_download /2024-izvestiya-27

Kiselenko, P. S. (2020). Izucheniye vliyaniya ekstrakta kornya eleuterokokka zhidkogo na nekotoryye immunobiokhimicheskiye pokazateli krovi telyat $[A$ study of the effect of the liquid Eleutherococcus root extract on some immunobiochemical parameters of calves' blood]. In Theory and practice of modern agricultural science. Collection of the 3rd national (allRussian) scientific conference with international participation pp. 553-555. ITS NGAU “Zolotoy kolos". https://nsau.edu.ru/file/868111

Kochish, I. I., Nesterov, V. V., Volchkova, L. A., Konovalova, E. M., Safarova, M. I., \& Kashkovskaya, L. M. (2019). Innovative approaches to stimulate natural resistance in calves. Veterinariya, zootekhniya $i$ biotekhnologiya, 9, 27-34. https://slib.com/issues/vzb_2019_09_a5/

Koryakina, L. P., \& Borisov, N. I. (2016). Sostoyaniye obmena veshchestv i yestestvennoy rezistentnosti v organizme novorozhdennykh telyat xThe state of metabolism and natural resistance in the body of newborn calves. Dostizheniya nauki i tekhniki APK, 30, 62-65. http://agroapk.ru/72-archive/01-2016/12612016-01-15-ru 


\section{Zaitsev et al,/Basrah J. Agric. Sci., 34(2): 184-192, 2021}

Loretts, O. G., Gorelik, A. S., Gorelik, O. V., \& Neverova, O. P. (2019). Increasing the natural resistance and safety of calves during the preweaning period. Nauchno-prakticheskie rekomendatsii. Ural State Agrarian University, Ekaterinburg. https://www.elibrary.ru/item.asp?id=38320300

Topuriya, L. Yu., \& Belyaeva, E. V. (2019). The use of immunostimulants to increase the resistance and safety of young calves. In Theory and practice of modern agricultural science. Collection of the 2nd national (allRussian) scientific conference (pp. 431-433). ITS NGAU “Zolotoy kolos”. https://nsau.edu.ru/file/748581
Zaytsev, V. V. (2019). [Physiological activity of hemostasis parameters in piglets that underwent an episode of overheating and received catosal]. Nauchnoye obozreniye. Biologicheskiye nauki [Scientific Review. Biological science], 3, 22-26. https://science-biology.ru/pdf/2019/3/1156.pdf

Zemlyanukhina, T. N. (2016). Blood morphological parameters and natural resistance of calves with different methods of rearing. Vestnik Altaiskogo gosudarstvennogo agrarnogo universiteta, 1(135), 117120. http://www.asau.ru/files/vestnik/2016/1/117120.pdf

\section{تأثير ملحق الكتلة الحيوية للغابات على المؤشرات الفسيولوجية المظهرية للعجول}

فلاديمير ف.زايتسيف1*، إيفان إن. مايوروف1، ليليا إم زايتسيفا 1فاسيلي ب.كوروتكي، فيكتور أ.ريزهوف2 ونيكولاي بورياكوف3 1 جامعة ولاية سمارة الزراعية ، 2 شارع أوشيبنايا ، أوست كينلسكي، 446442، روسيا

2مركز العلوم والتكنولوجيا "Khiminvest"، 6izhne-Volzhskaya naberezhnaya، نيجني نوفنورود، روسيا

3 الجامعة الروسية تيميريازيف الحكومية الزراعية، Timiryazevskaya، موسكو، روسيا

المستخلص: تعتبر تربية الحيوانات الصغيرة المقاومة للتأثيرات البيئية المختلفة والحفاظ عليها وتربيتها بنجاح أحد المعايير الرئيسية للإدارة الفعالة للثروة الحيوانية. يهدف البحث إلى دراسة مؤشرات المقاومة الطبيعية ومعدل نمو العجول تحت تأثير الاضافات الغذائية. أجريت الدراسة على أربع مجموعات من العجول البيضاء والسوداء، 10 رؤوس لكل منها، في سن 2-5 أثهر • تم تغذية عجول مجموعة السيطرة وفقًا للعليقة المعتمدة في المزرعة (العليقة الأساسية ، بما في ذلك قشور الحبوب والبقوليات، والحليب كامل الدسم، وبدائل الحليب، والمركزات، والطباشير، والملح). تم إعطاء حيوانات المجموعات التجريبية مكمل غذائي. في عمر 2-3 أشهر ، تم إعطاء العجول 12-23 غم. رأس -1، في عمر 3-4 أشهر - 19-38 غم. رأس -1، وفي عمر 4-5 أشهر - 23-47 غم. رأس 1مكمل غذائي يوميا. تتتاولت المقالة تأثير مكمل الكتلة الحيوية للغابات على المؤشرات الفسيولوجية المظهرية للعجول. تم دراسة تحليل الدم الكيموحياتي وخصائص عمليات التمثيل الغذائي في أجسام الحيوانات. اشارت النتائج الى أن استخدام مكمل غذائي بجرعة 30 غم. رأس -1 من الماشية في اليوم ساهم في تحقيق أعلى زيادة (9.9٪) في زيادة الوزن الحي لحيوانات التجارب وتحسين معايير المقاومة الطبيعية (نشاط مبيد للجراثيم لـ مصل الدم ، نشاط البلعمة من العدلات). استتادًا إلى بيانات اختبارات الدم الكيموحياتي واختبارات الدم، يمكن الاستتاج بأن اضافة مكمل غذائي في عليقة العجول الاساسية له تأثير إيجابي على مؤشرات المقاومة الطبيعية ومسار التمثيل الغذائي للنيتروجين. الكلمات المفتاحية: الاضافات العلفية ، الزيادة الوزنية، المؤشرات الكيميوحيوية ، المقاومة. 